\title{
ANÁLISE DE CAPA DE REVISTA: SUBSÍDIO AO ENSINO DE LEITURA DA LÍNGUA MATERNA
}

\section{Maria Cristiane de Freitas ${ }^{1}$}

Resumo: Os meios de comunicação percorrem a linguagem verbo-visual para transmitir as informações que não são totalmente percebidas pelo leitor, mas são importantes para estabelecer sentidos aos enunciados. O objetivo deste artigo é investigar mecanismos e estratégias linguístico-discursivas e visuais da revista ÉPOCA EDIÇÃO ESPECIAL na respectiva capa de uma edição que tratou da morte de Osama Bin Laden, para compreender a arquitetônica linguística das capas de revista em suas relações dialógicas com o leitor implícito e o contexto histórico-social de que faz parte. As análises apontam com clareza que a revista, apesar de ser um veículo de informação que deveria ser imparcial, deu um tratamento ao assunto de forma a apoiar todas as decisões tomadas pelo governo americano, encaminhando o leitor a concordar com essas tomadas de decisões, não Ihe restando alternativa. Este artigo está fundamentado na teoria dialógica da linguagem de Mikhail Bakhtin.

Palavras-chave: Leitura; Enunciado concreto; Linguagem verbo-visual; Capa de revista.

\footnotetext{
${ }^{1}$ Universidade do Vale do Paraíba, Brasil. E-mail: mchris.freitas@gmail.com.
} 